\title{
WAKAF: KAJIAN KOMUNIKASI YANG MEMOTIVASI UMAT UNTUK BERWAKAF
}

\author{
Nelly Nailatie Maarif \\ Dosen STIKOM-LSPR Jakarta \\ nelly.nm@1spr.edu \\ Usep Abdul Matin \\ Sekertaris Program Studi S3 SPs UIN Jakarta \\ usep.abdulmatin@uinjkt.ac.id
}

\begin{abstract}
Abstact
This paper argues that a key success of the implementation of waqf (wakaf/Islamic endowment) is the degree to which a nazir (nazhir/waqf supervisor) qualifies him/herself to develop waqf property in a trustworthy and productive way; therefore, he/she is capable of building trust of Muslim society (ummat) him/her. Additionally, success or failure of socializing and communicating this waqf execution to the society depends on the physical endowments; that is, at least the ummat know about the distribution of waqf. Here, the nazir is a key point in developing the waqf. The reason would be the fact that a prospective endower candidate often establishes fit and proper test to a nazir candidate. If the test convinces the endower candidate to trust the nazir, this candidate will automatically endow his/her own property for the sake of waqf. In opposite, if the test does not assure this potential endower, he/she will not accomplish his/her own property for the sake of waqf. This study found that a strategy of communication, which is employed by the nazir, helped convince him/her to lead the ummat to constitute the waqf of land inhabited by people of different areas. This research recommends that the nazir publicize waqf as well as Muhammadiyah organization has done it by its magazine; therefore, the ummat recognize the development of waqf, and this publicized waqf practice can become a good example of how the umat should execute their waqf programs.
\end{abstract}

Kata kunci: Wakaf, komunikasi, motivasi berwakaf.

\section{A. Pendahuluan}

Menurut Badan Wakaf Indonesia (BWI), yang merupakan kordinator nazhir di Indonesia yang mencatat perkembangan data tanah wakaf seluruh Indonesia, tahun 2013 tercatat bahwa tanah wakaf di Indonesia, berjumlah 
435.395 titik lokasi dengan luas 414.246.429 hektar. ${ }^{1}$ Lebih dari itu, Laporan Penghimpunan Gerakan Nasional Wakaf Uang di Indonesia memberikan informasi bahwa sampai dengan September 2014, jumlah wakaf uang yang terkumpul adalah Rp. 168,7 milyar. $^{2}$ Wakaf mempunyai potensi yang besar dalam membantu mengentaskan kemiskinan di negeri ini. Pemerintah Indonesia dengan menetapkan UU 41 tahun 2004 tentang wakaf, telah mendorong organisasi-organisasi filantropi di Indonesia bermunculan. Dalam hal ini disamping Badan Amil Zakat Nasional (BAZNAS), telah lahir 32 Badan Amil Zakat (BAZ) di tingkat provinsi dan 300 BAZ di tingkat kabupaten/kota. Badan Wakaf Indonesia (BWI) berperan sebagai koordinator nazhir wakaf tingkat nasional, dan BWI telah mensyahkan 100 Koperasi Jasa Keuangan Syariah (KJKS) atau Baitul Maal wa Tamwil (BMT), lembaga keuangan mikro (LKM) yang beroperasi berdasarkan prinsip-prinsip Syariah yang dalam artikel ini, khusus bergerak dalam bidang wakaf. BWI mencatat terdapat 3000 calon BMT yang akan segera disyahkan di Indonesia.

Potensi wakaf yang luar biasa besar ini bukan tanpa masalah. Dunia Islam secara umum, menurut Muhammad bin Ahmad bin Shalih As Shalih, dalam memanfaatkan peran wakaf untuk kebaikan dan kemaslahatan umat, memiliki dua masalah. Yaitu, pertama, semakin kurangnya kesadaran beragama di kalangan kaum Muslim. Hal ini mendorong mereka yang mampu dan berkecukupan untuk tidak mewakafkan sebagian harta mereka di jalan Allah. Kedua, Pengelola wakaf itu sendiri. Yakni, sebagian harta wakaf kaum Muslim tidak dikelola oleh pengelola dengan baik. Akhirnya, wakaf tersebut tidak bisa memberikan kontribusi dan peranannya secara maksimal.

Berdasarkan temuan kami di acara "Focus Group Discussion mengenai Strategi Badan Wakaf Indonesia dalam Memanfaatkan Komunikasi untuk Meningkatkan Minat Umat Melaksanakan Wakaf", kami memahami bahwa persoalan memotivasi umat untuk berwakaf menjadi persolan tersendiri di Indonesia. Populasi umat Muslim di Indonesia yang besar, melebihi 200.000.000 jiwa, tidak diimbangi oleh tingkat kepercayaan yang tinggi dari umat terhadap badan penglola wakaf atau nazhir. Korupsi yang terjadi yang dilakukan oleh oknum pejabat pemerintah di Indonesia merupakan faktor pemicu terbesar dari ketidakpercayaan umat terhadap pihak lain, terutama terhadap badan amal yang mengumpulkan dana dari masyarakat. Umat memiliki kecenderungan untuk melakukan wakaf langsung yang dilakukan secara mandiri dan langsung pada badan atau orang sebagai pengelola, seperti

\footnotetext{
${ }^{1}$ Wawancara dengan Ahmad Djunaidi, Direktur Eksekutif Badan Wakaf Indonesia, dalam acara "Focus Group Discussion mengenai Strategi Badan Wakaf Indonesia dalam Memanfaatkan Komunikasi untuk Meningkatkan Minat Umat Melaksanakan Wakaf," diselenggarakan pada hari Kamis, 11 Desember 2014, di Café Fifo, Ciputat, Tangerang Selatan.

${ }^{2}$ Wawancara dengan Ahmad Djunaidi, ibid.
} 
pengelola masjid, pengelola madrasah ataupun pada pengelola kegiaan sosial lain.

Alasan ini yang menyebabkan mengapa data resmi tanah wakaf atau pun wakaf uang masih belum setinggi yang diperkirakan. Benda wakaf atau dana wakaf yang diberikan secara langsung ini tidak tercatat dalam laporan resmi Badan Wakaf Indonesia (BWI) sebagai koordinator nazhir tingkat nasional. Salah satu jalan keluar yang terbaik adalah adanya transparansi semua kegiatan dan semua pelaporan tentang operasi, benda wakaf atau dana wakaf yang terkumpul, termasuk penggunaannya. Kegiatan ini diharapkan akan menumbuhkan kepercayaan umat terhadap badan amal secara bertahap. Kegiatan ini berarti membutuhkan komunikasi yang efektif dari badan amal kepada umat sebagai calon wakif (pewakaf). Pelaksanaan kegiatan wakaf di Indonesia perlu mendapat perhatian besar. Kendala yang menjadikan ketidakpercayaan masyarakat terhadap nazhir perlu diteliti, yang mungkin disebabkan oleh bukan hanya masalah ketidak percayaan masyarakat terhadap nazhir, akan tetapi bisa jadi karena kurang komunikasi yang kurang efekftif dalam usaha bagaimana memperkenalkan konsep wakaf pada masyarakat.

Minat umat Islam untuk mengenal wakaf lebih dalam, perlu mendapat perhatian lebih besar. Umat selayaknya mendapatkan informasi mengenai wakaf, sehingga dapat dipahami beberapa hal, seperti apa itu wakaf, apa manfaat wakaf bagi mereka baik di dunia maupun di akhirat, apa saja yang dapat diwakafkan, apa itu nadzir, kepada siapa atau dimana mereka dapat mencari informasi tentang nazhir atau badan amal wakaf. Umat seharusnya diberikan informasi, untuk menilai kredibilitas seorang nazhir. Umat sebagai calon wakif, harus memiliki kepercayaan terhadap nazhir, dan bersedia memberikan wakaf, untuk dikelola demi kebaikan dan kemaslahaan umat. Calon wakif atau pemberi wakaf, harus disadarkan bahwa mereka memiliki kemampuan untuk berbagi untuk membantu kaum dhuafa, serta mendorong calon wakif untuk bersedia secara sukarela dan sadar untuk mengeluarkan sebagian dari harta untuk dijadikan harta wakaf. ${ }^{3}$

\section{B. Sumber Pendapatan Masyarakat Islam}

Berikut di bawah ini daftar tentang terbagai sumber ${ }^{4}$ yang memberikan gambaran bagaimana masyarakat dan negara-negara Islam mengumpulkan pendapatan negara mereka:

1. Zakat

Secara Bahasa Zakat berarti tumbuh, berkembang dan berkah atau dapat pula berarti membersihkan atau mensucikan. Menurut istilah syari at, zakat berarti kewajiban atas harta atau kewajiban atas sejumlah harta tertentu untuk

\footnotetext{
${ }^{3}$ Wawancara dengan Ahmad Djunaidi, ibid.

${ }^{4}$ Ibid.
} 
kelompok tertentu dalam waktu tertentu. Dalilnya: "Dan dirikanlah shalat, tunaikanlah zakat, dan rukulah bersama orang-orang yang ruku!" (al-Qur'an: 2:43), Zakat dialokasikan kepada 8 asnaf, yaitu: Orang fakir, orang miskin, pengurus-pengurus zakat, para mu'llaf, hamba yang disuruh menebus dirinya, orang yang berhutang untuk jalan Allah, orang yang sedang dalam perjalanan, dan ibnu sabil.

\section{Kharaj}

Kharaj adalah hak kaum muslimin atas tanah yang ditaklukkan dari orang kafir, baik melalui peperangan maupun melalui jalan damai. Dalilnya: "(Juga) bagi para fuqara yang berhijrah yang diusir dari kampung halaman dan dari harta benda mereka (karena) mencari karunia dari Allah dan keridhaan(Nya) dan mereka menolong Allah dan Rasul-Nya. Mereka itulah orang-orang yang benar" (al-Qur'an: 59:8).

Dibawah ini dijelaskan pepajakan tanah menurut Abu Yusuf, didalamnya meliputi status dan jenis pajak yang akan dikenakan, yaitu:

Wilayah lain (luar Arabia) dibawah kekuasaan Islam, dibagi ke dalam tiga bagian: (1) wilayah yang diperoleh melalui peperangan; (2) wilayah yang diperoleh melalui perjanjian damai; dan (3) wilayah yang dimiliki oleh muslim di luar Arabia.

Wilayah yang berada dibawah perjanjian damai, yang dibagi ke dalam dua kategori: (1) penduduknya yang kemudian masuk Islam; (2) mereka yang tidak memeluk Islam.

$\square$ Tanah yang ditalukkan, yang dibagi ke dalam dua kategori: (1) ketika penduduknya masuk Islam sebelum kekalahan, maka tanah yang mereka miliki akan tetap menjadi milik mereka tetapi hanya menbayar usyr (membayar sepersepuluh pajak); (2) jika Khalifah mempunyai kebijakan untuk membagikan tanah tersebut kepada para pejuang, maka tanah ini wajib membayar kharaj.

\section{Ghanimah}

Ghanimah adalah segala sesuatu yang dikuasai oleh kaum muslim dari harta orang kafir melalui peperangan. Dalilnya:

"Ketahuilah, sesungguhnya apa saja yang dapat kamu peroleh sebagai rampasan perang, maka sesungguhnya seperlima untuk Allah, Rasul, kerabat Rasul, anak-anak yatim, orang-orang miskin dan ibn al-sabil, jika kamu beriman kepada Allah dan kepada apa yang Kami turunkan kepada hamba Kami (Muhammad) dihari furqan, yaitu di hari bertemunya dua pasukan. Dan Allah Maha Penguasa untuk segala sesuatu" (al-Qur'an: 8:41).

Dalam surat al-Anfal: 41. Allah SWT menentukan tata cara pembagian harta ghanimah dengan formulasi sebagai berikut: 
Seperlima bagian untuk Allah dan Rasul-Nya, dialokasikan bagi kesejahteraan umum dan untuk para kerabat, anak-anak yatim, orangorang miskin dan para musafir.

$\square$ Empat perlima bagian lainnya dibagikan kepada para angggota pasukan yang terlibat dalam peperangan.

4. Jizyah

Secara bahasa, jizyah berasal dari kata "jaza" yang berarti kompensasi Secara terminologi, jizyah adalah kewajiban yang dibebankan kepada penduduk non muslim yang tinggal di Negara Islam sebagai pengganti biaya pelindungan atas hidup, property dan kebebasan untuk menjalankan agama mereka. Dalilnya:

"Perangilah orang-orang yang tidak beriman kepada Allah dan tidak (pula) pada hari kemudian dan mereka tidak mengharamkan apa yang diharamkan oleh Allah Dan Rasul-Nya dan tidak beragama dengan agama yang benar (agama Allah), (yaitu orang-orang) yang diberikan Al-Kitab kepada mereka, sampai mereka membayar jizyah dengan patuh sedang mereka dalam keadaan tunduk." (QS. 9:29)

Pada masa Rasulullah SAW, besarnya jizyah satu dinar per tahun untuk orang dewasa yang mampu membayarnya. Perempuan, anak-anak, orang tua dibebaskan dari kewajiban jizyah. Diantara ahli kitab yang harus membayar jizyah sejauh yang diketahui adalah Nashara (orang-orang Kristiani) dari Najran.

\section{Usyr}

Al- 'Usyr bentuk jamaknya 'usyûr, yang artinya sepersepuluh.

Usyr merupakan pungutan sepersepuluh dari harta yang diperdagangkan ketika seseorang melintasi perbatasan suatu negara. Dalam hal ini, perlu direnungkan riwayat yang dituturkan oleh Uqbah bin Amir bahwa Nabi saw. pernah bersabda:

Tidak akan masuk surga orang yang memungut bea cukai. (HR. Abu Dawud, Ahmad, al-Baihaqi, al-Hakim, Ibn Khuzaimah).

Tarif Usyr ditetapkan sesuai dengan status pedagang.

Jika seseorang itu Muslim, maka ia akan dikenakan zakat perdagangan sebesar 2,5\% dari total barang yang dibawanya.

Jika ahl zimmah, dikenakan tarif sebesar $5 \%$.

Jika kafir harbi, dikenakan tarif sebesar 10\%. 


\section{Fay'}

Fay' adalah segala sesuatu yang dikuasai kaum Muslim dari harta orang kafir tanpa peperangan, termasuk harta yang mengikutinya, yaitu kharaj tanah tersebut, jizyah perorangan dan usyr dari perdagangan. Dalilnya:

“Apa saja harta rampasan (fay') yang diberikan Allah kepada Rasul-Nya yang berasal dari penduduk kota-kota maka adalah untuk Allah, Rasul, kerabat Rasul, anak-anak yatim, orang-orang miskin dan orang-orang yang dalam perjalanan, supaya harta itu jangan hanya beredar di antara orang-orang kaya saja di antara kamu. Apa yang diberikan Rasul kepadamu maka terimalah dia. Dan apa yang dilarangnya bagimu maka tinggalkanlah; dan bertaqwalah kepada Allah. Sesungguhnya Allah sangat keras hukuman-Nya" (al-Qur'an: 59:7).

Harta fay' dan semua harta yang mengikutinya seperti kharaj, jizyah, usyr merupakan harta yang boleh dimanfaatkan oleh kaum muslim dan disimpan dalam Baitu al-Mal. Semuanya termasuk kategori pajak dan merupakan sumber pendapatan tetap bagi Negara.

\section{Khums}

Khums adalah seperlima bagian yang diambil dari ghanimah. Dalilnya:

"Ketahuilah, sesungguhnya apa saja yang dapat kamu peroleh sebagai rampasan perang, maka sesungguhnya seperlima untuk Allah, Rasul, kerabat Rasul, anak-anak yatim, orang-orang miskin dan Ibnus-sabil, jika kamu beriman kepada Allah dan kepada apa yang Kami turunkan kepada hamba Kami (Muhammad) dihari Furqaan, yaitu di hari bertemunya dua pasukan. Dan Allah Maha Penguasa segala sesuatu" (al-Qur'an: 8:41).

Setelah Rasulullah wafat, bagian Rasulullah dan kerabat Rasulullah saw dimasukkan ke dalam Baitul Mal, untuk digunakan bagi kemaslahatan kaum muslimin dan jihad fi sabilillah. Objek khums adalah barang temuan dan barang tambang.

\section{Wakaf}

Secara bahasa wakaf berarti menahan, berhenti, atau diam.

Secara istilah wakaf adalah penahanan hak milik atas materi benda untuk tujuan menyedekahkan manfaat atau faedahnya. Dalilnya:

"kamu sekali-sekali tidahk sampai kepada kebajikan, sebelum kamu menafkahkan sebagian harta yang kamu cintai dan apa saja yang kamu nafkahkan. Maka sesungguhnya Allah Maha Mengetahui” (al-Qur'an: 3:92).

Wakaf memiliki fungsi sosial yang besar yaitu, aset yang sangat bernilai dalam pembangunan. Peranannya dalam pemerataan kesejahteraan di kalangan umat dan penanggulangan kemiskinan merupakan salah satu sasaran wakaf. 
9. Nawaib

Nawaib adalah pajak yang cukup besar yang dibebankan kepada kaum Muslim yang kaya. Nawaib ini ada dalam rangka menutupi pengeluaran negara selama masa darurat, dan ini pernah terjadi pada perang tabuk.

\section{Amwal Fadilah}

Amwal fadilah adalah harta kaum Muslim yang meninggal tanpa ahli waris atau muslim yang meninggalkan negerinya.

\section{Sedekah}

Kata sedekah berasal dari kata bahasa Arab, "shadaqah" yang berarti suatu pemberian yang diberikan oleh seorang Muslim kepada orang lain secara spontan dan sukarela tanpa dibatasi oleh waktu dan jumlah tertentu. Juga berarti suatu pemberian yang diberikan oleh seseorang sebagai kebajikan yang mengharap ridha Allah SWT dan pahala semata. Dalilnya:

"Tidak ada kebaikan pada kebanyakan bisikan-bisikan mereka, kecuali bisikan-bisikan dari orang yang menyuruh (manusia) memberi sedekah, atau berbuat maruf, atau mengadakan perdamaian diantara manusia. Dan barangsiapa yang berbuat demikian karena mencari keredhaan Allah, maka kelak Kami memberi kepadanya pahala yang besar" (al-Qur'an: 4:114).

Golongan yang berhak menerima sedekah yang disebutkan di dalam ayat tersebut sebagai adalah berikut:

Kerabat (yang miskin)

$\square$ Anak yatim (yang fakir)

Musafir

$\square$ Peminta-minta

$\square$ (biaya) untuk memerdekakan hamba sahaya.

\section{Hima}

Hima adalah perlindungan, menurut Abu Ubaid adalah tempat dari tanah yang tidak berpenduduk yang dilindungi kepala negara untuk tempat mengembala hewan-hewan ternak. Rasalulluh saw bersabda: "Orang Muslim adalah saudara bagi Muslim yang lainnya, yang memberi mereka keleluasaan air dan rumput."

Tanah hima ini mendapat perlindungan dari pemerintah, tetapi dapat dimanfaatkan oleh seluruh umat hasil dari pada tanah itu seperti air, rumput dan tanaman.

\section{Iqtha}

Iqtha adalah tanah yang diberikan oleh kepala Negara kepada seorang rakyatnya untuk menguasai sebidang tanah dengan mengabaikan yang lain. 
Dari Muhammad bin Ubaidillah as - Tsaqafi, beliau berkata, seseorang laki laki Basrah dari bani Tsaqafi keluar, disebutkan orang tersebut Nafi Abu Abdillah. Ia berkata kepada Umar RA, "Sebelum kami memiliki tanah di Basrah yang tidak termasuk tanah Kaharaj dan tidak merugikan seseorang dari kaum muslimin. Jika engkau memandang perlu meng'iqthakan, maka aku lakukan, aku hanya mengambil satu petakan untuk kudaku saja, lalu Umar menulis surat kepada Abu Musa al- Asy'ari, jika tanah itu seperti yang diceritakan maka petakanlah baginya." Mengenai status tanah ini, biasanya sebagai tanah usyr atau tanah kharaj. Abu Yusuf membaginya berdasarkan biaya irigasi. Penguasa akan menarik usyr, jika tanah itu diairi oleh buruhburuh secara manual. Tetapi Negara akan mengenakan pajak kharaj, jika tanah itu diairi secara ilmiah. Iqta biasanya diberikan kepada mereka yang telah berjasa bagi kaum muslim dan Negara Islam.

\section{Ihya al-Mawat}

Al-Mawat ialah tanah yang mati, tandus, tidak terurus, tidak ada pemiliknya dan tidak dimanfaatkan.

Ihya al-Mawat adalah membuka kembali lahan yang mati itu dengan membersihkannya, mengairi, mendirikan bangunan dan menanamkan kembali benih-benih kehidupan pada lahan tersebut. Menurut Abu Ubaid, bila tanah produk ihya al-mawat ini menghasilkan sesuatu dengan mengairi dan menanaminya, maka dikenakan zakat 1/10 untuk 8 mustahik zakat.

\section{Misahah.}

Misahah adalah metode perhitungan kharaj yang didasarkan pada pengukuran tanah tanpa memperhitungkan tingkat kesuburan tanah, sistem irigasi dan jenis tanaman.

\section{Konsep Harta yang Berwujud (Tangibel) dan Jasa (Intangibel).}

Konsep harta yang tangibel dan intangibel adalah mengenai penampilan fisik dari sebuah konsep harta. Kata tangible memberi arti bahwa benda atau harta terebut dapat di rasakan keberadaannya oleh indra perasa manusia, yaitu indra penglihatan manusia dan dapat dipegang fisiknya oleh indra manusia. Sedangkan konsep intangible menitik beratkan keberadaan harta yang dapat dirasakan keberadaannya oleh indra perasa manusia. Undang-Undang no. 41 tahun 2004 memberikan penjelasan yang sangat terperinci tentang bendabenda yang dapat dikatagorikan sebagai harta benda wakaf. Undang-Undang no. 41 tahun 2004 membagi harta benda wakaf sebagai harta bergerak dan harta tidak bergerak. Yang dimaksud dengan harta tak bergerak adalah harta benda seperti tanah, bangunan termasuk masjid, rumah, klinik kesehatan, jalan raya dan lain sebagainya. Sedangkan benda bergerak adalah uang, kendaraan 
berbagai jenis seperti mobil, motor dan sepeda. Saham dan hak cipta dikagorikan sebagai benda bergerak. ${ }^{5}$

Nasaruddin Umar, Wakil Ketua Dewan Pertimbangan Badan Wakaf Indonesia (BWI) periode 2011-2014, menjelaskan harta benda wakaf itu sebagai berikut:

"Modalnya kita tahan, tapi produktifitasnya kita kembangkan; itu wakaf produktif. Banyak hadist tentang wakaf. Jangan belanjakan modalnya! kirakira kalau kita pakai istilah sekarang "bunganya, manfaatkan hasilnya." Ada rukun wakaf, yaitu al-mal, yaitu harta benda apa saja yang dapat kita wakafkan. Bisa dalam bentuk materi, bisa dalam bentuk manfaat, misalnya sewa rumah saya. Saya punya 50 pintu dan saya wakafkan 2 pintu ke tetangga. Nah, itu wakaf harta. Yang dimaksud harta dalam wakaf boleh dalam bentuk uang, boleh dalam bentuk benda, seperti emas, boleh dalam bentuk tanah, bangunan dan manfaat."

Apa yang baru saja disebutkan oleh Nasaruddin Umar itu menjelaskan bahwa wakaf mencakup harta bergerak dan tidak bergerak.

\section{Pengertian Wakaf}

Wakaf atau wakf dalam bahasa Arab وقف, diucapkan waqf. Bentuk jamak dalam bahasa Arab: أوقاف, awqāf. Dalam bahasa Turki disebut vaklf. Dalam bahasa Urdu disebut وقف :Menurut Kamus Indonesia-Inggris, "wakaf" adalah 1) benda yang diberikan untuk ke pentingan agama atau masyarakat (property donated for religeous or community purposes); 2) badan amal (religeous foundation). Wakaf secara harfiah bermakna "pembatasan" atau "larangan". Makna wakaf diperoleh dari kata "al-habs," yang artinya melarang atau menahan. Melarang dalam arti tidak memperbolehkan benda wakaf menjadi hak milik seseorang dan menjadi obyek transaksi kepemilikan. Yang perlu diperhatikan adalah benda wakaf dalam hadits yang diriwayatkan oleh Umar ibn al-Khatab tidak menunjukkan keluarnya harta yang diwakafkan dari kepemilikan pewakif. Sementara berdasarkan terjemahan bebas Ensiklopedi Tematis Dunia Islam terbitan Ichtiar Baru Van Hoeve (IBVH), wakaf adalah menahan suatu benda yang kekal zatnya, dapat diambil manfaatnya, dan dipergunakan pada jalan kebaikan. Secara definisi, wakaf adalah pemberian yang dilakukan umat Islam pada badan amal, pendidikan atau untuk kepentingan kegiatan amal. Secara etimologi, wakaf berasal dari perkataan Arab "waqf," yang berarti "al-habs". ${ }^{6}$ Ia merupakan kata yang berbentuk masdar (infinitive noun) yang pada dasarnya berarti menahan, berhenti, atau diam. Apabila kata tersebut dihubungkan dengan harta, seperti tanah, binatang

\footnotetext{
${ }^{5}$ Untuk keterangan lebih lengkap, lihat Undang-Undang R.I. no. 4 tahun 2004 tentang Benda Wakaf.

${ }^{6}$ Amany Lubis, Para Perempuan dan Perluasan Budaya Wakaf, Al-Awaqaf Jurnal Wakaf dan Ekonomi Islam, Volume V, Nomor 1, January 2012, Badan Wakaf Indonesia, Jakarta (2012).
} 
dan lain-lainya, kata itu berarti pembekuan hak milik untuk faedah tertentu. Wakaf menurut Hanafiyah adalah menahan materi benda (al-'ain) milik wakif, dan menyedekahkan atau mewakafkan manfaatnya kepada siapapun yang diinginkan untuk tujuan kebajikan. ${ }^{7}$

\section{E. Prinsip Humanistik dalam Wakaf}

Bentuk filantropi penting dalam Islam adalah wakaf (waqf), yang berasal dari kata kerja "waqafa"-"yaqifu", yang berarti melindungi atau menahan. Sinonim wakaf meliputi tahbis, tasbil atau tahrim, meskipun ketiga istilah yang terakhir ini kalah populer di bandingkan dengan yang pertama. Seperti zakat, wakaf juga masuk ke dalam kategori sedekah. Mengenai shadaqah Rasulullah bersabda "Hindarililah api neraka walaupun dengan sepotong kurma. Jika engkau tidak mendapatkannya, maka cukup dengan menggunakan perkataan yang baik." Beliau juga bersabda "Tidak ada seorang hamba yang memberikan sedekah terbaik kecuali Allah juga akan memberikan ganti yang terbaik kepada keturunannya." Dalam hadits lain disebutkan "Sedekah itu menutup tujuh puluh tujuh pintu kejahatan." Wakaf merupakan bagian dari shadaqah yang juga memiliki keutamaan tersendiri.

Semangat wakaf dalam Islam ditunjukkan dalam hadits di bawah ini. Berbeda dengan shadaqah dan zakat, wakaf tidak diperintahkan (diwajibkan) secara eksplisit dalam Al-Quran. Meskipun demikian, beberapa ayat mengisyaratkan akan hal itu, seperti QS al-Baqarah (2):181, tentang wasiat dan QS al-Baqarah (2):19 yang memberi arahan tentang shadaqah. Selanjutnya ada ayat QS al-Baqarah (2): 44 dan 224 dan Ali 'Imran (3):92. Dua ayat pertama menggunakan kata birr (perbuatan baik), sedangkan ayat terakhir menggunakan infaq, yang keduanya merupakan padanan dari filantropi, seperti diuraikan di atas. Lebih jauh, diyakini bahwa tidak ada persoalan yang tidak dijelaskan oleh Al-Quran, meskipun secara sangat global, yang perinciannya biasanya ditemukan dalam hadits-hadits Nabi. Hukum wakaf termasuk ke dalam kategori ini, di mana penjelasannya secara eksplisit ditemukan dalam hadis-hadis Nabi, sementara Al-Quran hanya mengisyaratkan saja. Diantara hadits-hadits yang umum digunakan untuk menunjukkan anjuran wakaf adalah sebagai berikut.

Diriwayatkan dari Abi Hurayrah bahwa Nabi Saw. bersabda: Jika seorang manusia meninggal dunia, terputuslah amal perbuatannya kecuali tiga hal: shadaqah jariyah, ilmu yang di manfaatkan (orang lain), atau anak shaleh yang mendoakan kedua orang tuanya ${ }^{\circ}$ (H.R. Muslim), dan ayat lain adalah

${ }^{7}$ M. Cholil Nafis, Wakil Sekretaris Badan Wakaf Indonesia, Rethinking Fiqih Wakaf,

21 April 2011, didownload pada 29 September 2014 dari https://bwi.or.id/index.php/ar/publikasi/artikel/751-rethinking-fiqih-wakaf.html. 


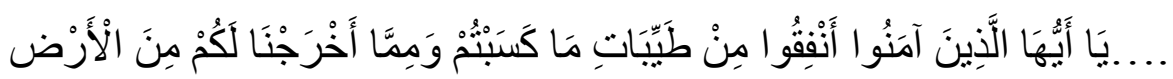

"Hai orang-orang yang beriman! Nafkahkanlah (di jalan Allah) sebagian dari hasil usaha kamu yang baik-baik, dan sebagian dari apa yang Kami keluarkan dari bumi untuk kamu." (Q.S. al-Baqarah (2): 267)

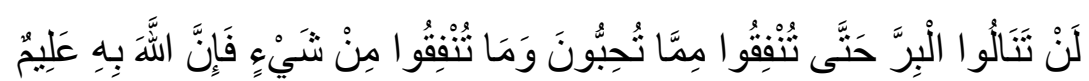

"Kamu sekali-kali tidak sampai kepada kebajikan (yang sempurna) sebelum kamu menafkahkan sebagian dari apa yang kamu cintai. Dan apa saja yang kamu nafkahkan, maka sesungguhnya Allah mengetahuinya." (Q.S. Ali Imran (3): 92)

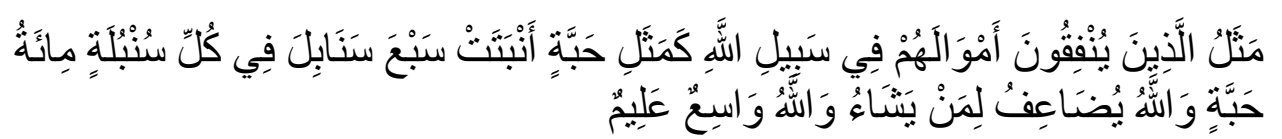

"Perumpamaan (nafkah yang dikeluarkan oleh) orang-orang yang menafkahkan hartanya dijalan Allah adalah serupa dengan sebutir benih yang menumbuhkan tujuh tangkai. Pada tiap-tiap tangkai seratus biji. Allah melipat gandakan (ganjaran) bagi siapa yang Dia kehendaki, dan Allah Maha Luas (karunia-Nya) lagi Maha Mengetahui.” (Q.S. al-Baqarah (2): 261)

M. Cholil Nafis, Wakil Sekretaris Badan Wakaf Indonesia periode 20112014, menjelaskan tentang prinsip wakaf yang sangat humanistik. Berdasarkan definisi dan arti kata wakaf, maka kepemilikan harta tetap ditangan wakif, bahkan wakif dapat menariknya sewaktu-waktu dan dapat pula menjualnya. Menurut Malikiyah, wakaf adalah menjadikan manfaat suatu harta yang dimiliki (walaupun pemilikannya dengan cara sewa) untuk diberikan kepada orang yang berhak dengan satu akad (shighat) dalam jangka waktu tertentu sesuai dengan keinginan wakif (al-Dasuqi: 2/187). Definisi ini menegaskan bahwa harta wakaf tidak lepas dari kepemilikan wakif, namun wakaf tersebut mencegah wakif melakukan tindakan yang dapat melepaskan kepemilikannya dan wakif berkewajiban menyedekahkan manfaat serta tidak boleh menarik. Menurut Syafi'iyah, wakaf adalah menahan harta yang bisa memberi manfaat serta kekal materi bendanya (al-'ain) dengan cara memutuskan hak pengelolaan yang dimiliki oleh wakif untuk diserahkan kepada nazhir yang dibolehkan oleh syariah (al-Syarbini: 2/376).

Wakif sudah melepaskan hartanya untuk wakaf, sehingga tidak boleh melakukan apa saja terhadap harta wakaf, tidak boleh menjual, mewariskan dan tidak boleh dihibah serta tidak boleh menariknya kembali. Golongan ini mensyaratkan harta yang diwakafkan harus harta yang kekal materi bendanya (al-'ain) dengan artian harta yang tidak mudah rusak atau musnah serta dapat diambil manfaatnya secara berterusan. Para ahli fiqif berpendapat tentang wakaf sebagai berikut: "Menurut Hanabilah, wakaf adalah bahasa yang 
sederhana, yaitu menahan asal harta (tanah) dan menyedekahkan manfaat yang dihasilkan (Ibnu Qudamah: 6/185)" Untuk memperjelas, di sini juga akan didiskusikan secara ringkas infak dan shadaqah. Keduanya memiliki hukum yang sama di luar zakat, yaitu sunnah. Menurut Al-Quran keduanya disebutkan dengan dua istilah yang berbeda. Ini tidak menutup kemungkinan akan adanya makna tersirat yang menunjukkan perbedaan antara keduanya. Memang, dua istilah ini berbeda, namun keduanya memiliki makna yang dapat saling dipertukarkan. Misalnya, ketika menafsirkan yunfiqun dalam QS alBaqarah: 2, infak di sini meliputi yang wajib, seperti kepada keluarga, dan sedekah sunnah (sadaqat al-tatawwu'). ${ }^{8}$

\section{F. Pengaturan Wakaf di Indonesia}

Menurut Widyawati dalam disertasinya yang berjudul "Filantropi Islam dan Kebijakan Negara pasca-Orde Baru: Studi tentang Undang-undang Zakat dan Undang-undang Wakaf, "filantropi Indonesia dari pra-kemerdekaan hingga pasca-Orde Baru berkembang melalui tiga arus utama. Pertama filantropi tradisional, yang bersumber pada agama dengan semangat dakwah. Kedua, organisasi masyarakat sipil yang mulai bermunculan pada 1970-an. Ketiga organisasi filantropi perusahaan dan organisasi sumber daya masyarakat sipil.

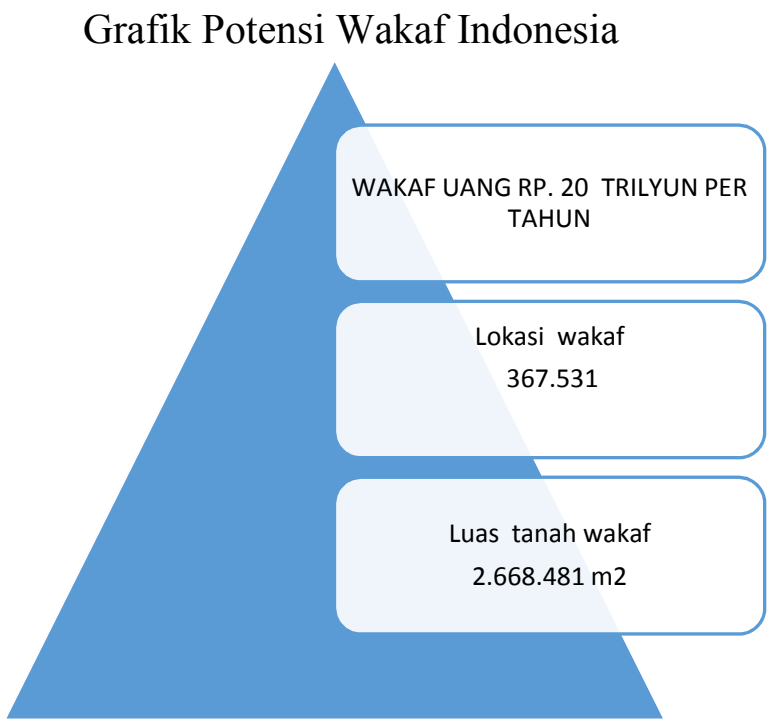

Sumber: Ahmad Djunaidi, Direktur Eksekutif Bada Wakaf Indonesia periode 2011 - 2014 pada Focus Group Discussion mengenai Strategi BWI dalam Memanfaatkan Komunikasi untuk Meningkatkan Minat Ummat Melaksanakan Wakaf, diselenggarakan di Ciputat, Tangerang Selatan, pada Kamis, 11 Desember 2014.

${ }^{8}$ M. Cholil Nafis, Wakil Sekretaris Badan Wakaf Indonesia periode 2011-2014, "Rethinking Waqf." 
Indonesia sebagai negara dengan penduduk mayoritas beragana Islam, diperkirakan memiliki lebih dari 180 juta jiwa kaum Muslim. Karena itu potensi wakaf Indonesia luar biasa besarnya. Dirjen Bimbingan Masyarakat Islam Prof. Dr. Nasaruddin Umar mengatakan, wakaf sebagai salah satu instrumen ekonomi umat Islam memiliki potensi yang besar. Bahkan potensi wakaf uang tunai bisa mencapai Rp 20 triliun pertahun. Namun potensi yang bisa menjadi soko guru perekonomian di Indonesia ini belum digarap maksimal. "Selama ini tidak mendapatkan perhatian serius dari semua pihak" kata Nasaruddin dalam acara sinergitas Direktorat Pemberdayaan Wakaf Kementerian Agama di Bandung, Jawa Barat, pada tanggal 27 April 2013. Menurut data dari Kementrian Agama Republik Indonesia, ditahun 2007 terdapat 367.531 lokasi wakaf di Indonesia dengan luas $2.668 .481 \mathrm{~m} 2$. Total luas tanah wakaf Indonesia ini adalah hampir sama dengan dua pertiga luas Singapore. ${ }^{9}$

Pendapat Nasaruddin ini didukung sepenuhnya oleh Ketua Umum Ikatan Ahli Ekonomi Islam Indonesia (IAEI), Mustafa Edwin Nasution, Menurut Edwin, wakaf uang bisa diibaratkan sebagai raksasa yang tertidur. Bila kekuatan raksasa itu dibangunkan, boleh jadi wakaf uang akan menjadi salah satu andalan umat Islam. Apalagi, setiap umat Islam bisa berwakaf uang,, tanpa harus menunggu kaya. Hanya dengan uang Rp 10 ribu sekalipun, umat Islam bisa menjadi seseorang wakif. Mustafa Edwin Nasution, mengungkapkan, potensi wakaf uang di Indonesia sangat besar, bisa mencapai Rp 20 triliun per tahunnya.

Direktur TWI) Zaim Saidi, mengungkapkan, potensi wakaf di Indonesia dapat mencapai sepertiga kekayaan umat Muslim. Potensi itu, menurut Zaim, diukur dari anjuran Rasulullah untuk berwakaf sebesar sepertiga harta yang dimiliki. "Jadi potensinya memang sangat luar biasa", Para ahli dibidang wakaf juga berpendapat bahwa wakaf uang bisa menjadi salah satu investasi akhirat bagi umat Islam. Dengan manfaat yang berlipat, wakaf uang akan menjadi pahala yang terus mengalir kepada wakif, meskipun sudah meninggal dunia. ${ }^{10}$ Sesungguhnya ekonomi umat dapat dibangkitkan melalui wakaf, kuncinya adalah motivasi yang tinggi dari umat Islam untuk melaksanakan wakaf itu sendiri.

${ }^{9}$ H. Nasaruddin Umar, Potensi wakaf Indonesia. Dirjen Bimbingan Masyarakat Islam, cum Wakil Ketua Dewan Pertimbangan Badan Wakaf Indonesia, in a program sinergitas Direktorat Pemberdayaan Wakaf Kementerian Agama di Bandung, Jawa Barat, (27.4.2013).

${ }^{10}$ Nasaruddin Umar, Wakit Ketua: Dewan Pertimbangan BWI periode 2011-2014 pada Focus Group Discussion mengenai Strategi BWI dalam Memanfaatkan Komunikasi untuk Meningkatkan Minat Ummat Melaksanakan Wakaf, diselenggarakan di Ciputat, Tangerang Selatan, pada Kamis, 11 Desember 2014. 
Grafik Penerimaan Wakaf Uang di Indonesia

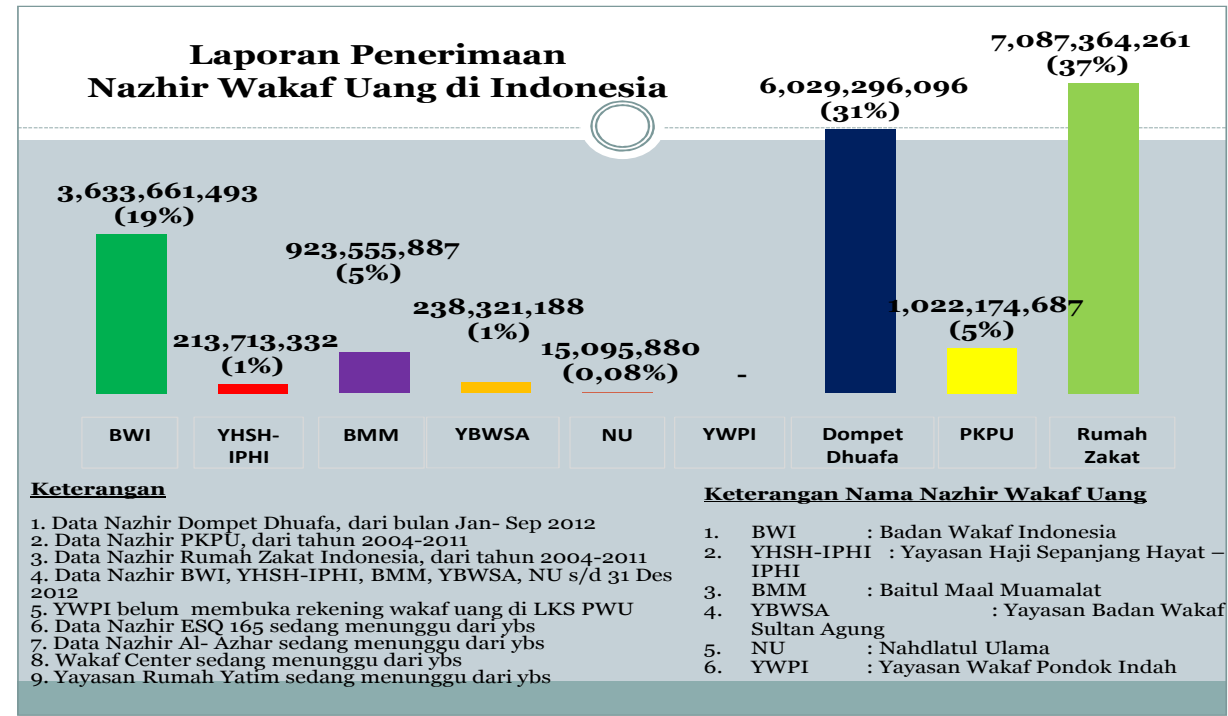

Sumber: Administrator Badan Wakaf Indonesia, Bahan Persentasi pada kunjungan mahasiswa program pascasarjana PSTTUI -Salemba di Badan Wakaf Indonesia, Jakarta (2013)

Dari segi wakaf uang, tabel di atas memperllihatkan bahwa secara keseluruhan sampai dengana tahun 2012 telah terkumpul wakaf uang sejumlah Rp. 19.1 milyar. Nazhir Rumah Zakat memiliki pendapatan tertinggi dari segi wakaf uang yaitu sejumlah Rp. 7.1 milyar atau 37\% dari total wakaf uang di Indonesia. Dompet Dhuafa dengan Rp. 6.1 milyar atau 31\% dari total wakaf uang, BWI sendiri sebagai nazhir berhasil mengumpulkan wakaf uang sejumlah Rp. 3,6 milyar atau $19 \%$ dari total wakaf uang nasional. Nazhir lain yang berjumlah lebih dari 15 badan amal memberikan kontribusi masingmasing antara kurang dari $1 \%$ sampai dengan 5\% dari total wakaf uang nasional. Jumlah pendapatan wakaf tunai ini masih sangat jauh di bawah potensi wakaf Indonesia yang diperkirakan bisa mencapai Rp 20 triliun per tahun untuk wakaf tunai saja.

\section{G. Undang-Undang Wakaf di era Pemerintah Republik Indonesia}

Sesudah perang kemerdekaan Republik Indonesia belum banyak yang terjadi yang berhubungan dengan wakaf. Baru pada tahun 1977 keluar Peraturan Pemerintah Republik Indonesia no. 28 tentang perwakafan tanah milik. Selanjutnya Menteri Agama mengeluarkan peraturan no. 1 tahun 1978 tentang Pelaksanaan Peraturan Pemerintah no. 28 tahun 1977 tentang Pemanfaatan Tanah Milik, Kompilasi Hukum Islam dan lain-lain. Melihat potensi wakaf yang luar biasa besarnya bagi pembangunan ekonomi dan kemaslahatan umat, Pemerintah Republik Indonesia kemudian mengukuhkan 
peraturan tentang wakaf melalui Undang-Undang no. 41 tahun 2004 dan pada tahun 2008 Pemerintah mengeluarkan Peraturan Pemerintah Pemerintah no. 42 tahun 2006 tentang Pelaksanaan Undang-Undang no. 41 tahun 2004. ${ }^{11}$

Wakaf dikenal oleh masyarakat sudah lama dan hal ini juga diteguhkan oleh Ahmad Djunaidi, ${ }^{12}$ Direktur Eksekutif Badan Wakaf Indonesia, mengenai data tanah wakaf. Sebagai contoh di Semarang terdapat wakaf seluas 100 ha berbentuk bangunan mesjid dan tanah yang sampai sekarang masih ada. Di Medan, Sultan mewakafkan tanah 50 ha. Di Banten, Sultan Maulana Hasanuddin mewakafkan tanahnya 1000 ha sekarang tinggal 100 ha. Sultan Maulana Yusuf mewakafkan tanah 500 ha, sekarang tinggal 50 hektar are.

\section{H. Strategi Penghimpunan Benda Wakaf di Indonesia dan beberapa Negara Islam}

Tanah wakaf di Indonesia saat ini sudah mencapai sekitar 430.000 persil lokasi dengan luas 4 milyar meter persegi. Melalui Program Nasional sertifikasi tanah wakaf (Pronas) 66\% tanah wakaf sudah memiliki sertifikat. BWI akan memgkoordinir program sertifikasi untuk 33\% tanah wakaf yang masih belum bersertifikat. Konsep wakaf yang baru diperkenalkan di Indonesia yaitu wakaf uang yang merupakan contoh dari wakaf benda bergerak. Wakaf juga dapat dilakukan dalam bentuk benda tak bergerak seperti contohnya tanah dan bangunan. Potensi wakaf uang di Indonesia juga sangat besar, bisa mencapai trilyunan Rupiah. Potensi wakaf yang besar ini sesungguhnya dapat menjadi soko guru dari perkembangan ekonomi masyarakat di Indonesia. Karena itu sosialisasi konsep wakaf harus diteruskan dan diharapkan dapat berkesinambungan. Tujuan utama dari kegiatan sosialisasi ini adalah agar masyarakat mau melakukan wakaf. Umat dapat menyalurkan wakaf ke BWI atau dapat juga menyalurkan wakaf mereka ke badan amal lain.

Badan atau lembaga sebagai organisasi yang mengumpulkan wakaf banyak tumbuh di Indonesia, artinya pelaksana kegiatan filantropi dalam pengumpulan wakaf dilakukan oleh umat, bukan negara. BWI atau Baznaz lebih berfungsi sebagai koordinator. Masjid atau madrasah berdiri, banyak dibangun oleh umat, apabila dinilai dengan jumlah uang, maka jumlah pembangunan yang dilakukan oleh umat bisa mencapai triliunan rupiah. Ini

\footnotetext{
${ }^{11}$ Widyawati, Filantropi Islam dan Kebijakan Negara pasca-Orde Baru: Studi tentang Undang-undang Zakat dan Undang-undang Wakaf, disertasi Program Doktor, Sekolah Pasca Sarjana Universitas Syarif Hidayatullah Jakarta (Maret 2011).

${ }^{12}$ Ahmad Djunaidi, Direktur Eksekutif Bada Wakaf Indonesia periode 2011 - 2014 pada Focus Group Discussion mengenai Strategi BWI dalam Memanfaatkan Komunikasi untuk Meningkatkan Minat Ummat Melaksanakan Wakaf, diselenggarakan di Ciputat, Tangerang Selatan, pada Kamis, 11 Desember 2014.
} 
membuktikan bahwa umat Islam di Indonesia sangat kuat dalam hal pelaksanaan konsep filantropi terutama wakaf.

Peraturan mengenai wakaf telah diatur melalui peraturan yang dikeluarkan Kementerian Agama RI dan BWI. Pemerintah dalam hal ini Kemetrian Agama RI dan BWI telah mengeluarkan peraturan tentang wakaf uang, sedangkan untuk wakaf benda tak bergerak seperti tanah, diserahkan langsung kepada nazhir. Dasar Hukum Perwakafan di Indonesia, bersumber kepada UU No. 41 tahun 2004 tentang wakaf, PP N0. 42 tahun 2006 tentang pelaksanaan UU No. 41, Peraturan Menteri Agama No. 4 tahun 2009 tentang administrasi pendaftaran wakaf uang, Keputusan Menteri Agama No. 73 tahun 2013 tentang tata cara perwakafan benda tidak bergerak dan benda bergerak selain uang, Keputusan Menteri Agama No. 92-96 tentang penetapan 5 LKS menjadi LKS PWU, Keputusan Dirjen Bimas Islam No. DJ.II/420 tahun 2009 tentang model, bentuk, dan spesifikasi formulir wakaf uang, Peraturan BWI tahun 2007 dan Peraturan BWI tahun 2012.

Hasil diskusi Penelitian Focus Group Discussion memberikan indikasi bahwa penghimpunan benda wakaf terdiri dari beberapa katagori. Katagori pertama: penghimpunan benda wakaf yang di kelola olah pemerintah. Katagori ini banyak terdapat pada Negara-neara di Timur Tengah seperti dijelaskan oleh Masykuri: "Di Timur Tengah hanya satu yang mengumpulkan wakaf yaitu Kementrian Agama, dan tidak ada lembaga lain".

Di Timur Tengah, termasuk Saudi Arabia, Mesir dan Turki, semua biaya kegiatan masjid dan madrasah dilaksanakan dan dibayar pemerintah. Pembangunan masjid dapat dilakukan oleh pihak swasta atau negara. Tetapi begitu masjid selesai harus diserahkan kepada negara karena akan diatur, dikelola dan dibiayai oleh negara. Semua personalia yang terlibat dalam kegiatan masjid dan wakaf ini termasuk khotib adalah pegawai negeri. Semua kegiatan termasuk bahan untuk ceramah para khotib disiapkan pemerintah, sehingga khotib atau dai itu tidak berbicara tentang hal-hal yang menurut pemerintah tidak mendukung pemikiran atau peraturan yang dibuat pemerintah. Dalam hal strategi komunikasi, benda wakaf dikelola sebagai wakaf produktif, berbentuk proyek apartemen untuk disewakan ada juga shopping centre. Semua informasi disebarkan keseluruh penduduk Negara.

Katagori kedua, penghimpunan benda wakaf yang di kelola olah nazhir perorangan. Menurut Ahmad Djunaidi, bahwa nazhir itu ada dua kelompok, yaitu nazhir tradisional bersifat perorangan dan nazhir dengan badan hukum yaitu nahzir professional. Nazhir tradisional umumnya dipilih oleh calon wakif karena dikenal secara pribadi. Karena itu, tidak ada strategi komunikasi khusus yang diterapkan nazhir persorangan. Menurut Djunaidi, nazhir tradisional umumnya tidak memiliki badan hukum.

Katagori ketiga, penghimpunan benda wakaf oleh badan amal professional. Badan amal yang beroperasi mengumpulkan wakaf, yang 
pengelolaannya dilakukan olah nazhir professional di Indonesia. Belum ada data resmi mengenai jumlah badan amal yang bertindak sebagai nazhir wakaf benda tak bergerak seperti tanah dan bangunan. Terdapat 82 nazhir wakaf uang, menurut catatan BWI sampai dengan September 2014. Tercatat resmi 13 Lembaga Keuangan Syariah Penerima Wakaf Uang.

Kelompok ketiga ini adalah kelompok yang paling potensial dalam mengembangkan wakaf di tanah air. Banyak lembaga pendidikan terutama pendidikan Islam yang didirikan dengan menggunakan harta benda wakaf. Organisasi masyarakat Islam Muhammadiyah adalah contoh yang paling menonjol dalam pemanfaatan harta benda wakaf untuk dunia pendidikan. Rumah sakit atau poliklinik juga merupakan fasilitas masyarakat umum yang paling popular dalam penggunaan harta benda wakaf di tanah air. Namun sayangnya, di Indonesia pemanfaatan harta benda wakaf lebih banyak harta benda konsuntif dan bukan harta benda produktif. Alasan utama karena memang harta benda yang diberikan sebagai wakaf adalah harta benda konsumtif seperti masjid, rumah sakit, poliklinik dan lain-lain. Hal ini menyebabkan timbulnya masalah dana untuk biaya pemeliharaan. Salah satu jalan keluar adalah dengan merubah fungsi harta konsumtif menjadi poroduktif.

Menurut Suparman Ibrahim, "fundraising" merupakan salah satu cara terbaik dalam mengumpulkan dana untuk membiayai operasi organisasi nir laba termasuk badan amal wakaf. Suparman juga berpendapat bahwa tujuan fundraising adalah:

1) Mobilizing fund (memanfaatkan dana yang tersedia).

2) Increasing the number of waqf (meningkatkan jumlah benda/jasa wakaf).

3) Improving image of nazhir (meningkatkan citra nazhir).

4) Maximizing relation (memanfaatkan hubungan dengan relasi) dan

5) Improving satisfaction (menigkatkan kepuasan kinerja). ${ }^{13}$

Tabel 1. Kapan terakhir memberi

\begin{tabular}{|l|l|l|}
\hline No. & Kapan terakhir memberi & Persentase (\%) \\
\hline 1 & Hari ini & $31 \%$ \\
\hline 2 & Kemarin & $22 \%$ \\
\hline 3 & Tiga hari yang lalu & $9 \%$ \\
\hline 4 & Seminggu yang lalu & $19 \%$ \\
\hline 5 & Sepuluh hari yang lalu & $3 \%$ \\
\hline
\end{tabular}

${ }^{13}$ Suparman Ibrahim, Fundraising Strategy of Cash Waqf, Al-Awqaf, Awaqf and Islamic Economic Journal, Special Edition, September 2011, Badan Wakaf Indonesia, Jakarta (2011), h.55 


\begin{tabular}{|l|l|l|}
\hline No. & Kapan terakhir memberi & Persentase (\%) \\
\hline 6 & Dua minggu yang lalu & $7 \%$ \\
\hline 7 & Tiga minggu yang lalu & $0 \%$ \\
\hline 8 & Sebulan yang lalu & $7 \%$ \\
\hline 9 & Dua bulan yang lalu & $1 \%$ \\
\hline 10 & Tiga bulan yang lalu & $1 \%$ \\
\hline & Total responden: 154 orang & \\
\hline
\end{tabular}

Sumber: Penelitian Perilaku Umat dalam ber-wakaf, penelitian pendekatan Analisis Deskriptif Statistika, Jakarta Timur, Maret s/d Juni 2014.

$31 \%$ dari responden mengatakan bahwa mereka melakukan pemberian setiap hari, 22\% menjawab bahwa mereka melakukan pemberian setiap dua hari sekali. Secara keseluruhan hampir $70 \%$ responden melakukan kegiatan memberi dalam minggu ini.

Tabel 2. Bentuk pemberian (shadaqah)

\begin{tabular}{|l|l|l|}
\hline No. & Bentuk Shadaqah & Persentase (\%) \\
\hline 1 & Uang & $56 \%$ \\
\hline 2 & Uang, pakaian & $17 \%$ \\
\hline 3 & Uang, pakaian, alat-alat ibadah & $7 \%$ \\
\hline 4 & Pakaian & $6 \%$ \\
\hline 5 & Uang, alat-alat ibadah & $5 \%$ \\
\hline 6 & Uang, pakaian, buku, majalah, alat-alat ibadah & $3 \%$ \\
\hline 7 & Tanah & $1 \%$ \\
\hline 8 & Uang, tanah & $1 \%$ \\
\hline 9 & Uang, pakaian, majalah & $1 \%$ \\
\hline 10 & Uang, pakaian, buku, majalah & $1 \%$ \\
\hline 11 & Uang, pakaian, buku, alat-alat ibadah & $1 \%$ \\
\hline 12 & Uang, pakaian, buku & $1 \%$ \\
\hline & Total responden: 154 orang & $100 \%$ \\
\hline
\end{tabular}

Sumber: Penelitian Perilaku Umat dalam ber-wakaf, penelitian pendekatan Analisis Deskriptif Statistika, Jakarta Timur, Maret s/d Juni 2014.

$56 \%$ responden lebih suka memberi dalam bentuk uang. Uang yang dikombinasikan dengan pakaian layak pakai, alat-alat ibadah seperti sajadah, mukenah merupakan alat shadaqah yang diminati sekitar $38 \%$ responden. Kombinasi uang, pakaian bekas layak pakai dan majalah serta alat ibadah juga diminati poleh sebagian kecil responden $(5 \%)$ 
Tabel 3. Pernah mendengar kata Wakaf

\begin{tabular}{|l|l|l|}
\hline No. & Pernah mendengar kata Wakaf & Persentase (\%) \\
\hline 1 & Pernah mendengar kata Wakaf ? & $90.8 \%$ \\
\hline 2 & Tidak pernah mendengar kata Wakaf? & $8.2 \%$ \\
\hline & Total responden: 154 orang & $100 \%$ \\
\hline
\end{tabular}

Sumber: Penelitian Perilaku Umat dalam ber-wakaf, penelitian pendekatan Analisis Deskriptif Statistika, Jakarta Timur, Maret s/d Juni 2014.

Hasil penelitian ini memperlihatkan bahwa mayoritas responden (90.8\%) pernah mendengar kata wakaf dan sangat sedikit dari umat Islam $(8.2 \%)$ yang belum pernah mendengar kata wakaf.

Tabel 4. Pertama kali memperkenalkan tentang konsep Wakaf

\begin{tabular}{|l|l|l|}
\hline No. & Sumber Informasi & Persentase (\%) \\
\hline 1 & Ceramah agama di masjid & $31 \%$ \\
\hline 2 & Guru Agama di SD & $18 \%$ \\
\hline 3 & Ceramah agama di TV & $17 \%$ \\
\hline 4 & Acara pengajian & $14 \%$ \\
\hline 5 & Guru sekolah / madrasah & $7 \%$ \\
\hline 6 & Orang tua-ibu & $7 \%$ \\
\hline 7 & Teman & $2 \%$ \\
\hline 8 & Ceramah agama di radio & $2 \%$ \\
\hline 9 & Buku agama & $2 \%$ \\
\hline 10 & Kakek & $1 \%$ \\
\hline 11 & Orang tua-ayah & $0 \%$ \\
\hline & Total responden: 154 orang & \\
\hline
\end{tabular}

Sumber: Penelitian Perilaku Umat dalam ber-wakaf, penelitian pendekatan Analisis Deskriptif Statistika, Jakarta Timur, Maret s/d Juni 2014.

Dalam hal wakaf, 91\% responden menjawab pernah mendengar kata wakaf. Mengenai sumber informasi pertama dari mana mereka mengenal kata wakaf. $31 \%$ responden menjawab dari kegiatan keagamaan di mesjid seperti pengajian, ceramah pada waktu kegiatan sholat berjamaah. 18\% dari mereka mengatakan bahwa pertama kali mendengar tentang kata wakaf dari guru mereka di sekolah dasar dan 7\% dari guru madrasah. 14\% mengatakan bahwa acara pengajian di mesjid memberikan pengetahuan pada mereka tentang konsep wakaf. Acara keagamaan di TV ternyata juga berperan karena sekitar $17 \%$ dari responden mengaku pertama kali mendengar tentang konsep wakaf melalui media elektronik ini. Yang juga cukup berperan memperkenalkan konsep wakaf pada anak-anaknya adalah seorang ibu (7\%). 
Hasil penelitian diatas memperlihatkan bahwa mesjid sangat berperan dalam memperkenalkan konsep wakaf pada jamaahnya. Kalau kita kelompokkan jawaban-jawaban diatas, dapat ditarik kesimpulan bahwa $25 \%$ dari pengenalan konsep wakaf dilakukan melalui kegiatan-kegiatan para guru mengajar ditingkat sekolah dasar. Para ibu juga berperan dalam memperkenalkan konsep wakaf. Orang tua terutama ibu dan kakek, teman, ceramah radio serta buku-buku keagamaan juga akan dapat dipertimbangkan untuk digunakan dalam memperkenalkan konsep wakaf pada masyarakat termasuk anak-anak.

Tabel 5. Pernah melaksanakan wakaf

\begin{tabular}{|l|l|l|}
\hline No. & Pernah melaksanakan wakaf & Persentase (\%) \\
\hline 1 & Pernah & $58.8 \%$ \\
\hline 2 & Tidak pernah & $41.2 \%$ \\
\hline & Total Responden: 154 orang & $100 \%$ \\
\hline
\end{tabular}

Sumber: Penelitian Perilaku Umat dalam ber-wakaf, penelitian pendekatan Analisis Deskriptif Statistika, Jakarta Timur, Maret s/d Juni 2014.

Walaupun responden-responden ini sudah pernah mendengar kata wakaf dan penjelasan tentang konsep wakaf, baru sekitar setengah dari mereka atau 55.8\% dari responden pernah melaksanakan wakaf.

Tabel 6. Arti Wakaf

\begin{tabular}{|l|l|l|}
\hline No. & Arti Wakaf bagi umat & Persentase (\%) \\
\hline 1 & $\begin{array}{l}\text { Memberikan sebagian dari milik atau harta } \\
\text { kepada orang lain untuk kepentingan kaum } \\
\text { miskin (dhuafa) }\end{array}$ & $52 \%$ \\
\hline 2 & $\begin{array}{l}\text { Memberi sebagian dari hak milik kepada sebuah } \\
\text { badan/ yayasan/ organisasi untuk kepentingan } \\
\text { masyarakat umum mis. Masjid, sekolah dll }\end{array}$ & $40 \%$ \\
\hline 3 & Memenuhi syariat Islam & $8 \%$ \\
\hline 4 & Lain-lain : membantu orang lain & $1 \%$ \\
\hline & Total responden: 154 orang & \\
\hline
\end{tabular}

Sumber: Penelitian Perilaku Umat dalam ber-wakaf, penelitian pendekatan Analisis Deskriptif Statistika, Jakarta Timur, Maret s/d Juni 2014.

$52 \%$ responden berpendapat arti wakaf bagi mereka adalah memberikan sebagian dari milik atau harta kepada orang lain untuk kepentingan kaum miskin (dhuafa). $40 \%$ berpendapat bahwa wakaf berarti memberi sebagian 
dari hak milik kepada sebuah badan/ yayasan/ organisasi untuk kepentingan masyarakat umum misal mesjid, sekolah dan lain-lain. Memenuhi syariat Islam dianggap oleh sekitar $8 \%$ responden sebagai arti dari wakaf bagi mereka.

Tabel 7. Tujuan melaksanakan wakaf

\begin{tabular}{|l|l|l|}
\hline No. & Tujuan melaksanakan wakaf? & Persentase (\%) \\
\hline 1 & $\begin{array}{l}\text { Untuk mendapat pahala dari Tuhan } \\
\text { (Allah SWT) }\end{array}$ & $46 \%$ \\
\hline 2 & Sebagai bekal di akhirat nanti & $23 \%$ \\
\hline 3 & Untuk membersihkan harta saya & $10 \%$ \\
\hline 4 & Untuk kemaslahatan umat & $10 \%$ \\
\hline 5 & Membantu kaum dhuafa & $9 \%$ \\
\hline 6 & Untuk membantu perkembangan organisasi & $2 \%$ \\
\hline & Total responden : 154 orang & $100 \%$ \\
\hline
\end{tabular}

Sumber: Penelitian Perilaku Umat dalam ber-wakaf, penelitian pendekatan Analisis Deskriptif Statistika, Jakarta Timur, Maret s/d Juni 2014.

Hanoir separuh responden (46\%) berpendapat bahwa mereka melaksanakan wakaf dengan tujuan untuk mendapat pahala dari Tuhan (Allah SWT). 23\% berpendapat bahwa wakaf merupakan bekal bagi suatu kehidupan dihari kemudian setelah meninggal, sebagai bekal di akhirat nanti. 10\% dari responden berpendapat bahwa wakaf akan mampu membersihkan harta mereka. Untuk kemaslahatan umat (10\%) dan membantu kaum dhuafa (9\%) merupakan alasan-alasan lain mengapa para responden berwakaf. Sebagian kecil responden berpikir untuk membantu perkembangan organisasi mereka melalui kegiatan wakaf.

Tabel 8. Jenis Benda Wakaf yang paling diminati

\begin{tabular}{|l|l|l|}
\hline No. & Bentuk Wakaf & Persentase (\%) \\
\hline 1 & Uang & $51 \%$ \\
\hline 2 & Uang, pakaian & $12 \%$ \\
\hline 3 & Uang, alat-alat ibadah & $12 \%$ \\
\hline 4 & Uang, pakaian, alat-alat ibadah & $12 \%$ \\
\hline 5 & Uang, pakaian, buku, majalah & $12 \%$ \\
\hline 6 & Alat-alat ibadah & $10 \%$ \\
\hline 7 & Pakaian & $8 \%$ \\
\hline 8 & Tanah & $11 \%$ \\
\hline 9 & Buku & $3 \%$ \\
\hline & Total responden : 154 orang & \\
\hline
\end{tabular}


Sumber: Penelitian Perilaku Umat dalam ber-wakaf, penelitian pendekatan Analisis Deskriptif Statistika, Jakarta Timur, Maret s/d Juni 2014.

Dalam tabel diatas dapat dilihat bahwa uang merupakan benda wakaf yang paling diminati oleh calon wakif. Benda lain yang juga diminati adalah tanah, buku, pakaian, dan alat-alat ibadah.

Tabel 9. Jenis Wakaf yang paling diminati Berdasar Jenis Profesi

\begin{tabular}{|l|l|l|}
\hline No. & Jenis Perofesi & Pilihan \\
\hline 1 & PNS & Uang \\
\hline 2 & BUMN & Pakaian \\
\hline 3 & Karyawan Swasta & Uang \\
\hline 4 & Pendidik & Uang \\
\hline 5 & Pensiunan & Uang \\
\hline 6 & Ibu Rumah Tangga & Uang \\
\hline & Total responden: 154 orang & \\
\hline
\end{tabular}

Sumber: Penelitian Perilaku Umat dalam ber-wakaf, penelitian pendekatan Analisis Deskriptif Statistika, Jakarta Timur, Maret s/d Juni 2014.

Bila dianalisa dari segi profesi ternyata hampir semua profesi memilih uang sebagai benda wakaf yang paling diminati, kecuali karyawan BUMN yang lebih cenderung untuk memilih pakaian bekas layak pakai.

Tabel 10. Jenis Benda Wakaf yang Paling Diminati Berdasar Tingkat Pendidikan

\begin{tabular}{|l|l|l|}
\hline No. & Pendidikan Terakhir/ setingkat dengan & Pilihan Utama \\
\hline 1 & SD (Sekolah Dasar) & Uang \\
\hline 2 & SMP (Sekolah Menengah Pertama) & Uang \\
\hline 3 & SMA /SMK (Sekolah Menengah Atas/Kejuruan) & Uang \\
\hline 4 & S1 (Sarjana Strata 1) & Uang \\
\hline 5 & S2 (Sarjana Strata 2) & - \\
\hline 6 & S3 (Sarjana Strata 3) & - \\
\hline & Jumlah responden: 154 orang & \\
\hline
\end{tabular}

Sumber: Penelitian Perilaku Umat dalam ber-wakaf, penelitian pendekatan Analisis Deskriptif Statistika, Jakarta Timur, Maret s/d Juni 2014.

Pemilihan benda wakaf dilihat darti latar belakang pendidikan, hasil penelitian memperlihatkan indikasi bahwa uang adalah benda. 


\section{Kunci Sukses Penghimpunan Benda Wakaf}

Menurut Uswatun, ${ }^{14}$ kunci sukses pelaksanaan wakaf adalah apabila nazhir dapat mengembangkan harta wakaf secara amanah dan produktif, sehingga dapat membangun kepercayaan masyarakat pada nazhir yang bersangkutan. Sukses atau tidak sosialisasi, tergantung kepada fisik wakaf. Sebagai contoh, di Jogja sekelompok orang datang kepada saya dan keluarga. Mereka bermaksud membangun rumah yatim piatu dan membutuhkan tanah wakaf. Saya dan keluarga melakukan beberapa pertanyaan terlebih dahulu, yang berkaitan dengan rencana tersebut, dan akhirnya saya dan keluarga, memberikan sebagian tanah untuk mereka. Peranan nazhir merupakan kunci pokok dalam pengembangan wakaf. Seperti contoh tersebut, merupakan bagian dari fit and proper test, setelah dinilai bagus, kami wakafkan sebagian tanah kepada mereka. Hasil pengembangan wakaf ternyata bagus dan penghuninya dari berbagai daerah.

Strategi komunikasi dari nazhir dalam mensosialisasikan kegiatandan perkembangan wakaf yang dikelola, memberikan kepercayaan pada masyarakat terhadap nazhir yang bersangkutan. Perkembangan wakaf, lebih baik dipublikasikan, sebagaimana yang dilakukan oleh majalah Muhammadiyah, sehingga masyarakat mengetahui perkembangan wakaf, dan dapat dijadikan sebagai contoh program wakaf. Majalah Muhamadiyah mempublikasikan wakaf produktif atau wakaf yang bersifat berkelanjutan, seperti peternakan ayam dan peternakan kambing.

\section{DAFTAR PUSTAKA}

Badan Wakaf Indonesia, Adminitrator"Bahan Persentasi pada kunjungan mahasiswa program pascasarjana PSTTUI" -Salemba di Badan Wakaf Indonesia, Jakarta (2013)

Djunaedi, Ahmad, Direktur Eksekutif Bada Wakaf Indonesia periode 2011 2014 pada "Focus Group Discussion mengenai Strategi BWI dalam Memanfaatkan Komunikasi untuk Meningkatkan Minat Ummat Melaksanakan Wakaf", diselenggarakan di Ciputat, Tangerang Selatan, pada Kamis, 11 Desember 2014.

Hasanah, Uswatun pada "Focus Group Discussion mengenai Strategi BWI dalam Memanfaatkan Komunikasi untuk Meningkatkan Minat Ummat Melaksanakan Wakaf", diselenggarakan di Ciputat, Tangerang Selatan, pada Kamis, 11 Desember 2014.

${ }^{14}$ Uswatun Hasanah pada "Focus Group Discussion mengenai Strategi BWI dalam Memanfaatkan Komunikasi untuk Meningkatkan Minat Ummat Melaksanakan Wakaf", diselenggarakan di Ciputat, Tangerang Selatan, pada Kamis, 11 Desember 2014. 
Ibrahim, Suparman, "Fundraising Strategy of Cash Waqf," Al-Awqaf, Awaqf and Islamic Economic Journal, Special Edition, September 2011, Badan Wakaf Indonesia, Jakarta (2011), h.55

Lubis, Amany, "Para Perempuan dan Perluasan Bdaya Wakaf", Al-Awaqaf Jurnal Wakaf dan Ekonomi Islam, Volume V, Nomor 1, January 2012, , Badan Wakaf Indonesia, Jakarta (2012).

Nafis, M. Cholil, Wakil Sekretaris Badan Wakaf Indonesia, "Rethinking Fiqih Wakaf", 21 أبريل 2011 di download dari website Badan Wakaf Indonesia, pada 29 September 2014.

Umar, H. Nasaruddin," Potensi wakaf Indonesia". Dirjen Bimbingan Masyarakat Islam, cum Wakil Ketua Dewan Pertimbangan Badan Wakaf Indonesia, in a program sinergitas Direktorat Pemberdayaan Wakaf Kementerian Agama di Bandung, Jawa Barat, (27.4.2013).

Umar, Nasaruddin, Wakit Ketua: Dewan Pertimbangan BWI periode 20112014 pada "Focus Group Discussion mengenai Strategi BWI dalam Memanfaatkan Komunikasi untuk Meningkatkan Minat Ummat Melaksanakan Wakaf", diselenggarakan di Ciputat, Tangerang Selatan, pada Kamis, 11 Desember 2014.

Widyawati, "Filantropi Islam dan Kebijakan Negara pasca-Orde Baru: Studi tentang Undang-undang Zakat dan Undang-undang Wakaf", disertasi Program Doktor, Sekolah Pasca Sarjana Universitas Syarif Hidayatullah Jakarta (Maret 2011). 